\title{
State, Institutions and Industrial Development in East Asian NICs
}

\author{
LAURIDS S. LAURIDSEN
}

During the last two decades, we have seen a wave of literature on the East Asian Newly Industrializing Countries (NICs). The majority of this literature is oriented towards the superior industrial performance of the East Asian NICs compared with other developing countries. In addressing this issue, the present article focusses on analytical and theoretical issues. It largely leaves out the empirical evidence and is more concerned with questions than answers. The answers that are given try to encapsulate what we already (think we) know, while the questions, hopefully, point out some of the areas where we ought to focus our future research in order to get a better understanding of the East Asian capitalist "miracles". The paper will not cover all possible types and levels of explanation but will concentrate on such factors as political and societal institutions. In the last section, however, a broader variety of determinants, including the external determinants, are discussed.

\section{Beyond Import Substitution: Export-Led Development}

The mainstream neoclassical debate on the NICs in the 1970s and 1980s was mainly concerned with the general superiority of outward-looking over inward-looking strategies (export-oriented industrialization over import substitution) and market-oriented strategies over state-led strategies. In the debate, the central focus was on the efficient allocation of resources. Following the theory of comparative advantages, it was argued that an outward-oriented trade regime would lead to a low level of price distortion which in turn would result in maximization of the rate of long-term growth. These neoclassical arguments, however, have both theoretical and empirical shortcomings. 
First, although there have been attempts to supplement this basically static approach with a dynamic perspective which should link export and freer markets to economic growth and development, the theoretical foundation is certainly frail. ${ }^{1}$ Moreover, various studies have questioned the empirical evidence supporting the proposition that an outward-oriented trade policy is causally linked with the degree of price distortion and with superior economic growth. ${ }^{2}$ Finally, several studies have demonstrated that the East Asian NICs (South Korea and Taiwan in particular) have been much less outward-oriented in their trade policy than claimed in the neoclassical literature. The level of protection was not particularly low and neither industry neutrality nor trade neutrality was prevalent. $^{3}$

A particular aspect of the above mentioned debate has to do with the role of the state in industrial development. In general export-led growth was seen as combined with minimal state intervention. This aspect was highlighted in the neoclassical political economy literature of the 1980s which converted the neoclassical anti-import substitution critique into an anti-interventionist discourse, in which state failures were seen as predominant and worse than market failures, and in which market failures were considered as almost exclusively policy induced. It further supported the argument for export-oriented strategies. Thus, it was asserted that export-oriented activities were not subject to rent-seeking activities. Apart from the fact that the relative size and significance of market failures versus government failures is an empirical question, the link between particular trade strategies on the one hand and rent-seeking on the other hand has so far been postulated rather than substantiated. ${ }^{4}$

Still, the East Asian NICs constitute a puzzle in the neoclassical universe. In the recent literature which goes beyond the market, this puzzle has been solved by arguing that the East Asian economies have intervened market-friendly, i.e., have disciplined their interventions with international and domestic competition; have intervened competently, pragmatically and flexibly; have intervened in a non-distortingly way; and finally have intervened moderately and openly, following "rules rather than official discretion." ${ }^{.5}$

Radical globalist writings have accepted the starting point that the economic success of the East Asian NICs is linked to the shift to 
export-led growth but criticize the voluntarist tone among the neoclassical economists. ${ }^{6}$ It has been argued that the "success of the East Asian NICs rested not only on certain discrete policies but on the particular political and institutional context that allowed the NICs to adopt those policies in the first place." ${ }^{17}$ In explaining the different choices of strategy in Latin America and East Asia, several explanations have been put forward. According to Mahon, we can distinguish between: explanations which are based upon the character and relative weight of interests in civil society; explanations which put emphasis on state autonomy vis-à-vis societal interests; explanations which stress the international pressures and the severity of payment crisis; and finally, explanations which focus on structural and hence political obstacles to exporting low-wage manufactured goods. ${ }^{8}$

From the above brief review of some of the literature which makes cross-regional comparisons between East Asia NICs and (in particular) Latin American countries, we can observe that the political economy of industrialization is becoming a key area in the debate. A major weakness in this type of literature is the uncritical acceptance of the neoclassical starting point, i.e., that the main difference in industrial performance between Latin America and East Asia has to do with the superiority of export-oriented over import substitution industrialization. This point of departure is explicitly put forward by Haggard:

The crucial difference between industrialization in East Asian and Latin American NICs is the difference between industrialization through export and import substitution; a central puzzle is to examine the conditions under which the East Asian countries adopted and sustained the policy reforms that produces export-led growth. ${ }^{9}$

Although export of manufactures is common to all of the four East Asian NICs, one should not refrain from asking the following questions: How important and how significant was the shift from import substitution. (ISI) to export-orientation (EOI) in the early 1960s? What is meant by a shift from ISI to EOI? Does it refer to a shift in the net overall balance of incentives for production directed to the domestic market versus export, or does it refer to a shift in 
trade shares, i.e., the share of trade/export in GDP? Furthermore, to what extent was East Asia's fast growth and fairly equitable income distribution a result of export-led growth, i.e., caused by export growth?

On the one hand, one can question the proposition that there was significant change in the early 1960s towards economic liberalization, i.e., towards an open, outward-oriented and market-led strategy. In both South Korea and Taiwan, a non-neutral trade regime was prevalent and both governments promoted and even forced private producers to export. In South Korea, the state used both the carrot and the stick to push exports, one main mechanism being to give access to the profitable domestic markets in exchange for improved export performance. ${ }^{10}$ Similarly, in Taiwan, export was supported but in ways that differed significantly from free trade or neutral trade regimes. ${ }^{11}$

On the other hand, although one should not ignore the vital importance of domestic demand expansion for economic growth, export of manufactures has been important for economic development in both Taiwan and South Korea. Export of manufactures became a vital source of foreign exchange, and to a great extent the East Asian NICs did not just import in order to export but exported in order to import. Particularly in Korea, export industries constituted a means of converting unskilled labour into sophisticated imports. Moreover, export also served to relieve the demand constraint in the fairly small domestic market (in Taiwan). Finally, export undoubtedly disciplined firms to improve their product quality, and increased labour utilization, thus leading to a higher market pressure on wages.

Therefore, the question is not whether export was important for industrial development in Taiwan and South Korea but whether it really. was the key factor. Furthermore, we have to keep in mind that export of manufactures might have been a result of, rather than the reason why output increased. 


\section{Beyond the Market : State-Led Development}

As there are good reasons to believe that trade policy orientation and trade orientation per se are not dominant determinants of growth and structural transformation, it is not surprising that more emphasis has been put on the qualitative aspects of state intervention, i.e., the extent to which policies are implemented as originally formulated (hardness and softness of policies). The theoretical challenge then is not to explain policy differences or the degree of state intervention but to explain the effectiveness of state intervention. Jenkins has argued:

The key to superior industrial performance of the East Asian NICs ... is rather the ability to direct the accumulation process in the direction which is required by the capitalist development at a particular point in time which is crucial. ${ }^{12}$

In this structuralist-statist perspective, effective state intervention is considered a necessary condition for successful industrial development. The change towards growth and structural transformation that leads to the rise of skill and high-value added industries, which are able in the long run to compete in the domestic market and internationally on cost and product quality, requires more than market signals, and the state is considered as the only entity with sufficient resources, coercive power and legitimacy to make that type of beyond-the-market interventions.

Robert Wade has described the central economic mechanism of the capitalist developmental state by referring to a combination of "the use of state power to raise the economy's investible surplus; insure that a high portion is invested in productive capacity within the national territory; guide investments into industries that are important for the economy's ability to sustain higher wages in the future; and expose the investment projects to international competitive pressure whether directly or indirectly." ${ }^{\text {"13 }}$

As mentioned above the main point is not about quantity but the quality of state intervention, and the type of state intervention that is referred to goes beyond both macro-economic policies which only affect overall demand, and functional industrial policies which aim at affecting a function across all/many industries. ${ }^{14}$ 
Four main features of a more strategic type of intervention are often referred to: selectivity, flexibility, coherence and competitive orientation. Selectivity, in that the state creates and supports progressively shifting competitive advantages instead of just adapting to existing comparative advantages. Flexibility, in the sense that the shifting international conjunctures and the shifting "windows of opportunity" in the world market demand a high adjustment capacity of the state. Coherence, in the sense that their impact is cumulative. Finally, competitive in the sense that policy promotes competitive production in enterprises. ${ }^{15}$

The ability of the state to design and undertake such selective and directive interventions should not be taken for granted. Apart from the availability of sufficient and appropriate policy instruments, certain institutional or organizational requirements are important, and they constitute what has been named a developmental state. A developmental state is characterized by having internally a high level of bureaucratic capacity taking the form of a stable, welldeveloped, coherent, competent and non-corrupt bureaucracy; and by having externally both a high level of absolute autonomy from classes and groups which derive their wealth from unproductive (zero-sum) activities (or which are otherwise inimical to long term national capitalist industrial development) and a high level of relative autonomy from particular groups of industrial capitalists. ${ }^{16}$ A variety of studies have dealt with the specific historical circumstances which have produced the political and institutional bases which in turn have contributed to a high level of autonomy and bureaucratic capacity in the East Asian NICs compared with the NICs in other regions. ${ }^{17}$

Shifting the perspective from an inter-regional comparison of all NICs to an intra-regional comparison between the Asian NICs, one is confronted with the fact that although all states probably govern the market, they do so in different ways and with different methods. Obviously, South Korea has followed an aggressive industrial policy. In contrast, the KMT state in Taiwan has taken a more decentralized approach, utilizing large public upstream enterprises, state-sponsored R\&D institutions and selected foreign investors to push the industrial transformation, and guiding 
Taiwan's myriad of small and medium-sized enterprises through a set of incentives. ${ }^{18}$

In my opinion, the literature has documented that a statist approach has much more explanatory power than a market-oriented approach. Castells probably is correct in his analysis when he states that "behind the economic performance of the Asian Tigers breathes the dragon of the developmental state."19

A developmental state perspective, however, is not without puzzles. For example, if a developmental state is so important for good economic performance, how has Hong Kong then developed without such a state? That anomaly has been attacked with reference to one or a combination of the following arguments : "Hong Kong is a special case"; "Hong Kong has done less well"; "Hong Kong is a developmental state due to its widespread intervention in the sphere of collective consumption, and due to the role played by large financial and commercial enterprises in cooperation with the colonial state elite." ${ }^{120}$ Leaving Hong Kong aside, we still need more knowledge about how Taiwan and South Korea have avoided government failures, that is, avoided disastrous and wasteful decisions and avoided the self-interested behaviour of bureaucrats. In short, if the state disciplines certain private actors and particular private enterprises, who, then, disciplines state actors?

Moreover, one could ask whether the extent of state guidance is related to the "stage" of industrial development, the argument being that certain forms of competition involve more complex structural interdependencies and therefore require greater strategic capacity. Following Michael Porter, Bob Jessop has suggested a distinction between Ricardian, Kaldorian and Schumpeterian forms of competition and related types of states - Japan being closer to the latter form while Hong Kong tentatively is placed in the first category. The three different forms of competition are: First, the Ricardian, which is factor driven, i.e., depends on factor endowment and on the ability to minimize production costs with a given division of labour. Secondly, the Kaldorian form of competition which is investment-driven and rests on dynamic growth efficiency - a form "which relies on the dynamic causation of investment in the sectors or industries with high productivity growth and 
expanding markets and involving making allocative decisions among available processes and products with regard to the likely repercussions of any (re-)allocation on economic growth." ${ }^{.21}$ Thirdly, the Schumpeterian competitive strategy which is innovation driven and depends on a dynamic innovation efficiency, i.e., depends on particular process, product or organizational innovations. ${ }^{22}$

Finally, we need more information on the extent to which and the mechanisms by which the state has guided the small and mediumsized enterprises. While South Korea with its tight big business-state interaction fits well into the developmental state framework the question remains as to what extent the Taiwanese state has been able to govern its plethora of small and medium-sized companies. In contrast to the neoclassical approach, which links the success of Taiwan to the small and medium-sized enterprises in downstream industries, the statist literature seems to have been concerned primarily with large-scale firms in upstream industries. The precise linkages between big and small enterprises, however, are not very well researched.

\section{Beyond Market and State: Institution-Led Development}

In contrast to statist approaches in political science, which try to bring politics back in by focussing on the state as the most significant institution and by "getting inside the state," the new institutionalism in sociology and theories of organization has been more concerned with societal institutions. The emergence of industrial winners are seen less as a result of diligent centralized planning than as a result of particular context sensitive factors, i.e., institutional and organizational factors as they have developed historically in different societies.

In the new sociological institutionalism economic action is situated in a social context. Economic action is not carried out by "the economic man as a supersmart selfish individual without history and tradition, without enemies and friends."23 People consider others when they do business. Economic action is embedded in ongoing networks of personal relationships. Networks 
"refer to a regular set of contacts and similar social connections among individuals or groups."24 Thus, economic action is embedded in networks of institutionalized relationships - in routinized and organized procedures and ways of doing things. Moreover, as argued by Biggart, "the particular character of embeddedness network of relations, social beliefs, gender and family structure and other institutionalized form of social order such as state and religion - will vary across societies. ${ }^{125}$

The relevance of new sociological institutionalism in relation to late industrialization is revealed in the comparative work of Hamilton, Biggart and Orrú on structures of business ethics, networks of ownership and production, and the concrete arrangements which govern investment and trade in Japan, South Korea and Taiwan. All three countries have organizations and markets built upon principles of group and network which from a neoclassical perspective is normally interpreted as institutional "imperfections" or "distortions". The main aim of their analyses, however, is to disaggregate and explain the different qualities of these networks - the different organizing principles - that can be found in structures of business networks (and state-business networks) in these three countries. These differences, as illustrated in table 1 below, show: the Japanese communitarian principles of cooperative and relational contracting between equal and unequal partners organized around large, bank-financed group firms; the South Korean corporate patrimonialism organized around large family owned and state financed family groups - chaebols; and finally, the Taiwanese patrilineal logic of familial networks of usually informal or reinvestment financed family firms. ${ }^{26}$ 
Table 1. Business Structure and Business/State Relationships in Japan, South Korea and Taiwan

\begin{tabular}{|c|c|c|c|}
\hline & Japan & South Korea & Taiwan \\
\hline $\begin{array}{l}\text { State-business } \\
\text { relations }\end{array}$ & $\begin{array}{l}\text { Cooperative } \\
\text { partnership }\end{array}$ & Political capitalism & Separation of spheres \\
\hline $\begin{array}{l}\text { Principal corporate } \\
\text { actors }\end{array}$ & Inter-market groups & Chaebol & Family firms \\
\hline $\begin{array}{l}\text { Intra-firm } \\
\text { managerial strategies }\end{array}$ & $\begin{array}{l}\text { Company ideologies; } \\
\text { consensus building; } \\
\text { peer group controls }\end{array}$ & $\begin{array}{l}\text { State Confucianism, } \\
\text { impersonal } \\
\text { management; strong, } \\
\text { centralized control }\end{array}$ & $\begin{array}{l}\text { "Family style" } \\
\text { management; control } \\
\text { through personal ties }\end{array}$ \\
\hline $\begin{array}{l}\text { Extra-firm market } \\
\text { strategies }\end{array}$ & $\begin{array}{l}\text { High R\&D; } \\
\text { manufacture and } \\
\text { marketing of new } \\
\text { products }\end{array}$ & $\begin{array}{l}\text { High capital ventures } \\
\text { in established } \\
\text { markets }\end{array}$ & $\begin{array}{l}\text { Low capital; low } \\
\text { R\&D; manufacture of } \\
\text { consumer } \\
\text { expendables }\end{array}$ \\
\hline
\end{tabular}

Source: Hamilton and Biggart 1991, 207.

Moreover, these three different types of business network have all adapted well to the capitalist world market, and the table illustrates that (apart from such areas as electronics) they are not necessarily in competition with each other:

Taiwan's system of small family firms, which can flexibly shift from producing one commodity to another, has become a dominant producer of an extensive range of medium-to-highquality consumer goods (e.g., clothes, small household items) of the kind that fill the modern home and office but that require very little research and development. Large Japanese corporations specialize in a product area and, through research, development, and marketing strategies, attempt to create new commodities and consumers for those commodities ... Exploiting their competitive advantage in technology and mass production, Japanese businesses operate on the frontier of product development. With the entire economy orchestrated by the state, South Korean business are 
attempting to become important producers of commodities that require extensive capital investment but for which markets already exist (e.g. steel, major construction materials, automobiles). Such ventures require large amounts of capital and coordination but relatively little research and development. ${ }^{27}$

It is quite obvious that these different types of business network in the same cultural area cannot be explained by reference to universal economic laws and undifferentiated cost-benefit calculations or to abstract cultural uniformities. According to Hamilton and others, a clearer comprehension of how these organizational structures and practices came into being and how they are reproduced, requires a historical and context sensitive analysis showing how the preexisting interaction patterns or institutional principles have shaped these practices:

Each economy rests on institutional principles that provide a coherent logic for competitive economic action. Socially constructed, accepted models of correct market behaviour shape interfirm relations, prompting firms to behave with and against each other in characteristically homogeneous ways. To be "technically" efficient, firms must consider and comply with the institutional setting in which they are embedded ... East Asian economies have prospered not because they have unilaterally adapted to technical environmental requirements, but because they have successfully institutionalized the principles of market activity suited to their socio-cultural environment and to their strategies of economic development. ${ }^{28}$

The new economic sociology is mainly concerned with explaining different patterns of industrial organization and how they are shaped by the way firms are embedded in different institutional networks. As these networks are different in each society, they allow for activation of different organizational designs to achieve industrialization.

A network approach seems to provide us with useful investigative tools. It allows us to understand the significant 
differences between the South Korean state-guided oligopolistic type of capitalist industrialization and the Taiwanese type of flexible capitalism in which small and medium-sized enterprises have played a predominant role. A network approach allows us to look much more into the nature of production, distribution, and information networks. Further, it allows us to analyze Taiwanese industrialization along an ethnic dimension as a tension between the state-capitalist project of the KMT and the family enterprise strategy of the local Taiwanese. We are, however, also left with many open questions.

First, one can question whether the three different patterns of business are just complementary strategies. We also have to look into the disadvantages of small family enterprises. In his analysis of the electronics industry, Mody shows that South Korean firms have a superior performance and he emphasizes the weaknesses in the Taiwanese small-scale approach. ${ }^{29}$

Second, we need to know more about the character of the highly developed division of labour and the related subcontracting networks both nationally and internationally. ${ }^{30}$

Third, it is necessary to know more about the role of big business in Taiwan's subcontracting system, and particularly the role played by large upstream producers as input suppliers, capital suppliers, personnel suppliers and as marketing channels to and for downstream small and medium-sized firms. ${ }^{31}$

Finally, realizing that the Taiwanese state has not followed a "hands off" strategy, we question the suggestion of the new sociological institutionalism that the successful growth of Taiwanese economy "has not taken place because of diligent, centralized planning; rather, it has occurred because of the entrepreneurship of the small and medium firms in the private sector, in the absence of strong incentives for growth ..."132

\section{Towards a Framework of Analysis: Cluster of Institutions}

The present article has concentrated on the extent to which determinants of East Asia's or rather Taiwan's and South Korea's 
development performance can be found in approaches of a marketoriented, state-oriented or institution-oriented kind. Before summing up, it may be useful to widen the scope of possible determinants.

First, the rise and the success of the East Asian NICs cannot be analyzed in an international vacuum. Most scholars agree that several factors related to the world economy and the post-war inter-state system have favoured the Asian NICs. Among the favourable world market conditions one can mention world trade expansion; preferential access to the American market; relocation of production by American Multinational Corporations (MNC), partly as a response to the intensified Japanese penetration of the American market; and the role of Japan as a model for these countries. As a result of the post-war East Asian geo-politics these countries were given a special treatment. One aspect was foreign aid which played a special role in the process of primitive capital accumulation and agrarian transformation, and which in general strengthened the East Asian state elites relative to societal forces. In short, world system factors created a favourable set of conditions and opportunities for industrial "take-off".

Second, the historical legacies and the initial conditions must be taken into account. The Japanese colonialism provided Taiwan and South Korea with favourable infrastructural, bureaucratic, educational and agricultural preconditions for industrial transformation. Moreover, such factors as limited national resource endowments and small internal markets should be taken into account when these countries are compared with large and resource-rich countries such as the Latin American NICs. Finally, one should be aware that Taiwan and South Korea probably did not qualify as typical underdeveloped countries in the 1950s - a fact which must have important implications for the lessons that can be drawn for other countries. ${ }^{33}$

Third, the question is not whether culture is important, but how to integrate culture in analysis. One possibility is to focus at some static, fundamental, and abstract common values (such as Confucianism) and discuss how they affect individual behaviour and organizational patterns. Apart from the difficulties that arise when we have to explain cross-national or cross-regional differences in the same cultural area and differences over time plus the difficulties in identifying these values among people, such a strategy 
normally tends to overlook that certain politico-economic developments often have formed contemporary "cultural phenomena". To illustrate this point: familism and entrepreneurialism in Taiwan is not just a reflection of the traditional Chinese values, but is also a result of KMT's politically motivated preference for small-scale local Taiwanese enterprises, KMT's policy of leaving reproduction to the family and the KMT nation building program. ${ }^{34}$ It might therefore be preferable to consider culture as something that is historically situated, affected by agency and power and mediated through certain institutions. ${ }^{35}$

Fourth, power, interests and social coalitions matter. The main focus in this paper has been on the state as an actor, but we have to acknowledge the relational character of state strength and study social forces in order to explain both state autonomy and the capacity of the state to implement particular policies. Thus, a study of the state as an actor must take into account the independent organizational, political and economic resources of social classes and groups and must look at the interplay of political forces and interests, and specify the coalitional structure or pacts of domination behind state intervention.

If we want to avoid reducing the complex to the simple and the differentiated to the uniform, the above mentioned sets of explanatory variables cannot be left out. Nevertheless, this paper suggests that in order to obtain further insight into both the dynamics and the diversity of capitalist industrial development in East Asia, future research should more fully investigate the way in which particular institutions - encompassing both institutions-asorganization ("institutional arrangements") and institutions-as-rulesof-game ("institutional environments") - have shaped, limited and channeled social actions.

There is no such thing as normal capitalist accumulation but only different trajectories and patterns of capitalist industrial development which are embedded in the local cultural and sociopolitical context. Interpretations of the East Asian NICs which consider them as market-led tend to abstract from and ignore these essential institutional aspects, while explanatory frameworks of both state-led and institutional-led kind tend to be much more sensitive to context, history and institutions. Interpretations of the statist 
kind are forced to investigate the institutional requirements making effective state intervention possible, and approaches of the institution-led kind highlight the social fabric of investment, production and trade interaction and make it clear that microlevel institutions such as the family and social networks affect economic performance.

The scope for institutional analysis, however, must be widened further. Sayer and Walker have suggested that one should study series of modes of organization. First, the basic triad covering the workplace, the firm and the market as institutions. Second, the middle ground covering a web of inter-firm alliances and networks (including family ties, associational links etc.) over, under and around firms and markets. Third, Sayer and Walker point at territories and nation states as important organizational entities at the final level of modes of industrial organization. ${ }^{36}$ More precisely, Sayer and Walker says:

Our second theme is that there exists a very wide range of modes of integration. Every branch of industry consists of nested and interpolated layers of social institutions, orchestrated through diverse points of control. Just as workplaces are systems of specialized work units, and the firms are systems of workplaces, so there are systems of firms, embedded in a delicate fabric of collaboration, contracts, ownership, families, and like. In addition regional and national systems of firms and networks, even system of states must be woven into the full web of industrial production. ${ }^{37}$

By widening the scope of institutional analysis, new aspects of East Asian capitalism come into focus. Although high profit rates in East Asia were immediately related to high levels of labour extraction, highly educated and productive labour, super-exploitation of young female workers and the related tight control over labour, the workplace and the "politics of production" is often ignored. Efficiently and profitably bringing together labour, materials and machinery cannot be taken for granted but must be explained by reference not only to labour repression but also to other types of labour control and integration. Burawoy's writings on factory regimes and Frederic Deyo's analysis of labour systems in East Asia 
constitute valuable points of departure. ${ }^{38}$ In the case of South Korea, for example, more research on the workplace is needed to understand the contradictory interaction between authoritarian control, paternalistic management practices and some kind of workers' participation at the operational level of production. ${ }^{39}$

Moreover, it is useful to look at the firm as an institution. In the case of South Korea, the structure and management of a business group must be taken into account, ${ }^{40}$ and in the case of Taiwan, flexible management policies through interpersonal networks and the horizontal proliferation of the family enterprise must be given more notice. ${ }^{41}$

Beyond workplace and firms we also need to know much more about various kinds of supply, production, export and marketing networks. Apart from what has already been mentioned, such an analysis might highlight the institutional requirement which made entry into new world markets possible. In the real world (which is different from the neoclassical textbook world) information on relevant suppliers, information on tastes, quality standards and marketing requirements cannot be taken for granted but must be explained by reference to state policy and institutional settings.

\section{Conclusion}

Capitalist industrialization never proceeds independently of the concrete institutional and historical context. This is true for East Asian industrialization as well as for industrialization experiences in the West. Generally, scholars who look at the East Asian NIC's from a market-led perspective tend to ignore this fact and favour more simple, uni-dimensional and ahistorical models which can easily be transferred to and emulated by other developing countries. As indicated, the present author intends to search for promising research avenues inside more institutional oriented approaches which look either at institutional aspects of the state or at societal institutions. Instead of seeing a fundamental tension between statist and societal oriented approaches, an institutional approach focussing on both state and societal institutions may prove more fruitful. What we should look for, however, is not single institutions 
but clusters or ensembles of institutions and the way they are linked to particular patterns of industrialization and levels of economic performance.

The developmental state debate has allowed us to "come inside the state" and has pointed out a set of institutional and organizational preconditions for effective state intervention. Similarly, the new institutional sociology and related studies have succeeded in "getting society back in" - in getting the social fabric of production, distribution and consumption into focus. The link to production, however, is still a "missing link" and we are forced to ask still more questions: To what extent is market guidance a necessary condition for different types of industrial transformation and competition? To what extent are the organizational principles, highlighted in the new institutional sociology, country specific or sector specific or locality specific? These and other questions mentioned above must be explored in future research, if we wish to get beyond what we already (think we) know.

Laurids S. Lauridsen, is Associate Professor, Institute of Geography and International Development Studies, Roskilde University, Denmark.

\section{NOTES}

1 G.K. Helleiner, "Trade Strategy in Mid-Term Adjustment," World Development, Vol. 18, No. 6 (1990); Robert Wade, Governing the Market: Economic Theory and the Role of Government in East Asian Industrialization (Princeton, New Jersey: Princeton University Press, 1990); Robert Wade, "Managing Trade: Taiwan and South Korea as Challenges to Economics and Political Science," Comparative Politics, Vol. 25, No. 2 (January 1993).

2 Colin I. Bradford, "NICs and the Next-Tier BICs as Transnational Economies," in Colin I. Bradford and William H. Branson, Trade and
Structural Change in the Pacific Asia, (London: The University of Chicago Press, 1987); Hans W. Singer and Patricia Gray, "Trade Policy and Growth of Developing Countries: Some New Data," World Development, Vol. 16, No. 3 (1988); Wade, Governing the Market; Santo Dodaro, "Comparative Advantage, Trade and Growth: Export-Led Growth Revisited," World Development, Vol. 19, No. 9 (1991).

3 Richard Luedde-Neurath, "State Intervention and Export-oriented Development in South Korea," in Gordon White, ed., Developmental States in East Asia (London: MacMillan 
Press, 1988); Clive Hamilton, Capitalist Industrialization in Korea (Boulder, Colerado: Westview Press, 1986); Wade, Governing the Market; Rhys Jenkins, "Learning from the Gang: Are there Lessons for Latin America from East Asia," Bulletin of Latin American Research, Vol. 10, No. 1 (1991).

4 Helen Shapiro and Lance Taylor, "The State and Industrial Strategy," World Development, Vol. 18, No. 6. (1990); Stephan Haggard, Pathways from the Periphery: The Politics of Growth in the Newly Industrializing Countries (Ithaca and London: Cornell University Press, 1990), p. 16.

5 World Bank, World Development Report, 1991: The Challenge of Development (New York: Oxford University Press, 1991).

6 Haggard, Pathways from the Periphery; James E. Mahon, "Was Latin America Too Rich to Prosper? Structural and Political Obstacles to Export-Led Industrial Growth," The Journal of Development Studies, Vol. 28, No. 2 (January 1992).

7 Haggard, Pathways from the Periphery, p. 21.

8 Mahon, "Was Latin America Too Rich to Prosper?"

9 Haggard, Pathways from the Periphery, p. 12.

10 Leroy P. Jones and Il Sakong, Government, Business, and Entrepreneurship in Economic Development: The Korean Case (Cambridge, Massachusetts and London: Harvard University Press, 1980); Hamilton, Capitalist Industrialization in Korea, $\mathrm{p}$. 44 and pp. 125-26; Larry Westphal, "Industrial Policy in an ExportPropelled Economy: Lessons from South Korea's Experience," Journal of Economic Perspectives, Vol. 4, No. 3 (Summer 1990); Alice Amsden, Asia's Next Giant: South Korea and Late Industrialization (New York and Oxford: Oxford University Press, 1989).

11 Wade, Governing the Market; Robert Wade,"East Asia's Economic Success:
Conflicting Perspectives, Partial Insights and Shaky Evidence," World Politics, No. 44 (1992); Wade, "Managing Trade: Taiwan and South Korea as Challenges to Economics and Political Science."

12 Rhys Jenkins, "The political Economy of Industrialization: A Comparison of Latin American and East Asean Newly Industrializing Countries," Development and Change, Vol. 22 (1991), pp. 197-231, p. 224.

13 Wade, Governing the Market, p. 342. 14 Ibid., pp. 28-29; Robert Wade, "Industrial Policy in East Asia: Does It Lead or Follow the Market?," in Gary Gereffi and Donald L. Wyman, Manufacturing Miracles: Paths of Industrialization in Latin America and East Asia (Princeton, New York: Princeton University Press, 1990), p. 233ff; Wade, "East Asia's Economic Success," pp. 299-300.

15 Jenkins, "The political Economy of Industrialization;" Robert Wade, "The Role of Government in Overcoming Market Failure: Taiwan, Republic of Korea and Japan," in Helen Hughes, ed, Achieving Industrialization in East Asia (Cambridge, New York : Cambridge University Press, 1988); Wade, Governing the Market.

16 Dietrich Rueschemeyer and Peter B. Evans, "The State and Economic Transformation: Toward an Analysis of the Conditions Underlying Effective Intervention," in Peter B. Evans, Dietrich Rueschemeyer, and Theda Skocpol, eds., Bringing the State Back In (New York: Cambridge University Press, 1985); Peter B. Evans, "Predatory, Developmental, and Other Apparatuses: A Comparative Political Economy Perspective on the Third World State," Sociological Forum, Vol. 4, No. 4 (1989); for an overview see Laurids S. Lauridsen, "The Debate on the Developmental State," in John Martinussen, ed, Development Theory and the Role of the State in Third World Countries, Occasional Paper, International Development Studies, Roskilde University, No. 2 (1992). 
17 Haggard, Pathways from the Periphery; Wade, Governing the Market; Jenkins, "Learning from the Gang;" Thomas B. Gold, State and Society in the Taiwan Miracle (New York: M.E. Sharpe, 1986); White, ed., Developmental States in East Asia; Richard P. Appelbaum and Jeffrey Henderson, eds., States and Development in the Pacific Rim (London and New Delhi: Sage, 1992).

18 Wade, Governing the Market, p. 370; Wade, "The Role of Government in Overcoming Market Failure," pp. 146-147; Christopher Ellison and Gary Gereffi, "Explaining Strategies and Patterns of Industrial Development," in Gereffi and Wyman, eds., Manufacturing Miracles, pp. 384-386; Manuel Castells, "Four Asian Tigers With a Dragon Head: A Comparative Analysis of the State, Economy and Society in the Asian Pacific Rim," in Appelbaum and Henderson, eds., States and Development in the Pacific Rim.

19 Castells, "Four Asian Tigers With a Dragon Head," p. 55.

20 Ibid., pp. 45-50; Wade, Governing the Market, pp. 331-341; Wade, "The Role of Government in Overcoming Market Failure," p. 152; Haggard, Pathways from the Periphery, pp. 121125.

21 Bob Jessop, "The Schumpeterian Workfare State; or 'On Japanism and Post-Fordism'," paper presented to the Eigth Conference of Europeanists, Chicago, March 27-29, 1992, pp. 6-7; see also Michael Porter, The Competitive Advantage of Nations (London: MacMillan, 1990), pp. 543558.

22 In this process of disaggregation Jessop also suggests a distinction to be made between welfare states and workfare states, the latter denoting that state intervention subordinates welfare policy to competitiveness by promoting flexible labour markets and flexible types of collective provision. The state in both Japan and the East Asian NICs falls in the workfare category. Moreover, Jessop emphasizes that states can be found in neo-liberal, neo-corporatist or neostatist versions, depending upon institutional legacies and the balance of political forces. Neoliberalism promotes a market-guided transition; neo-corporatism relies on ex-ante coordination of the economic agents, while neo-statism represents a stateguided approach to economic transformation and competitiveness through intervention from outside and above the market mechanisms. Finally, Jessop stresses that the required institutional capacities advance as we move from Ricardian to Kaldorian and onwards to Schumpeterian competitive strategies. Each step represents a more radical approach to competitiveness but the precise organizational mechanism markets, corporatist arrangements or state - can not be specified in advance.

23 Nicole Woolsey Biggart, "Explaining Asian Economic Organization: Towards a Weberian Institutional Perspective," Theory and Society, Vol. 21, No. 20 (1991), pp. 216-217.

24 Richard Svedberg and Mark Granovetter, "Introduction," in Granovetter and Svedberg, eds., The Sociology of Economic Life (Boulder, San Francisco, and Oxford: Westview Press, 1992), p. 9.

25 Biggart, "Explaining Asian Economic Organization," p. 221.

26 Gary G. Hamilton and Nicole Woolsey Biggart, "Market, Culture and Authority: A Comparative Analysis of Management and Organization in the Far East," in Granovetter and Svedberg, The Sociology of Economic Life; Marco Orrú, Nicole Woolsey Biggart and Gary C. Hamilton, "Organizational Isomorphism in East Asia," in Walter W. Powell and Paul J. DiMaggio, eds., The New Institutionalism in Organizational Analysis (Chicago and London: The University of Chicago, 1991); Marco Orrú, "The Institutional Logic of Small-Firm Economies in 
Italy and Taiwan," Studies in Comparative International Development (Spring 1991); Biggart, "Explaining Asian Economic Organization."

27 Hamilton and Biggart, "Market, Culture and Authority," p. 208.

28 Orrú, Biggart and Hamilton, "Organizational Isomorphism in East Asia," p. 363 and p. 387.

29 Ashoka Mody, "Institutions and Dynamic Comparative Advantage: the Electronics Industry in South Korea and Taiwan," Cambridge Journal of Economics, No. 14 (1990).

30 Compare Gwo-Shyong, Shieh, "Manufacturing 'Bosses': Subcontracting Networks under Dependent Capitalism in Taiwan," Ph.D dissertation, University of California at Berkeley, 1990; Ellison and Gereffi, "Explaining Strategies and Patterns of Industrial Development;" and Gary Gereffi, "New Realities of Industrial Development in East Asia and Latin America: Global, Regional, and National Trends," in Appelbaum and Henderson, eds. States and Development in the Pacific Rim.

31 Compare Alice Amsden, "Big Business and Urban Congestion in Taiwan: The Origins of Small Enterprise and Regionally Decentralized Industry (Respectively)," World Development, Vol. 19, No. 9 (1991); Wade, Governing the Market, p. 110; and Gary Gereffi, "Big Business and the State", in Gereffi and Wyman, eds., Manufacturing Miracles, p. 98.

32 Orrú, "The Institutional Logic of Small-Firm Economies in Italy and Taiwan," p. 23.

33 For further reflection on this point see Lars Mjøset, "Comparative Typologies of Development Patterns: The Menzel/Senghaas Framework," in Lars Mjøset, ed., Contributions to the Comparative Study of Development: Proceedings from. Vilhelm Aubert Memorial Symposion 1990, Vol. 2 (Oslo: Institute for Social Research, 1992), p. 140; and Wade, Governing the Market, p. 108.
34 Susan Greenhalgh, "Networks and their Nodes: Urban Society on Taiwan," The China Quarterly, Vol. 99 (September, 1984); Susan Greenhalgh, "Families and Networks in Taiwan's Economic Development," in A. Winckler and Susan Greenhalgh, eds., Contending Approaches to the Political Economy of Taiwan (Armonk, New York and London: M.E. Sharpe, 1988); Wade, Governing the Market, p. 296.

35 Compare Jeffrey Henderson and Richard P. Appelbaum, "Situating the State in the East Asian Development process," in Appelbaum and Henderson, eds., States and Development in the Pacific Rim, pp. 15-17; and Ellison and Gereffi, "Explaining Strategies and Patterns of Industrial Development."

36 Andrew Sayer and Richard Walker, The New Social Economy: Reworking the Division of Labor (Cambridge, Massachusetts and Oxford: Blackwell, 1992), chapter 3; for an example of the relevance of regional institutions in a Korean context, see for instance, Myung-Rae Cho, "Large-Small Firm Relations, Flexibility and Regional Clusters in South Korea" (mimeographed, 1993).

37 Sayer and Walker, The New Social Economy, p. 160.

38 Michael Burawoy, The Politics of Production (London and New York: Verso, 1985); Frederic C. Deyo, Beneath the Miracle: Labor Subordination in the New Asian Industrialism (Berkeley: University of California Press, 1989); Laurids S. Lauridsen, "Labour and Democracy in Taiwan? Continuity and Change of Labour Regimes and Political Regimes in Taiwan," Research Report, No. 87, Publications from the Institute of Geography, SocioEconomic Analysis and Computer Science, Roskilde University Centre (1992).

39 For a detailed discussion, see Laurids S. Lauridsen, "New Technologies, Flexibilization and Changing Capital-Labour Relations - 
the East Asian NICs, with Special Reference to Taiwan and South Korea," Research Report, No. 88, Publications from the Institute of Geography, Socio-Economic Analysis and Computer Science, Roskilde University Centre (1992).

40 See in particular Amsden, Asia's Next Giant.
41 Compare Siu-lun Wong, "The Applicability of Asian Family Values to Other Socio-cultural Settings," in Peter L. Berger and Hsin-Huang Michael Hsiao, eds., In Search of an East Asian Development Model (New Brunswick and Oxford: Transaction Books, 1988); and Greenhalgh, "Families and Networks in Taiwan's Economic Development." 